\title{
CrimRxiv
}

\section{Predictors of Revictimization in Online Dating}

Fatemeh Fereidooni, Judith Daniels, Miriam Lommen

Published on: Mar 01, 2022

DOI: 10.21428/cb6ab371.21a82294

License: Creative Commons Attribution 4.0 International License (CC-BY 4.0). 
